\title{
GRANIČNI NAGIB KRETNOSTI SKIDERA S VITLOM TEMELJEM VUČNE ZNAČAJKE VOZILA
}

\section{GRADEABILITY OF THE CABLE SKIDDER BASED ON TRACTION PERFORMANCE}

\author{
Tomislav PORŠINSKY, Vitomir KAJGANA, Željko TOMAŠIĆ, Andreja ĐUKA*
}

\begin{abstract}
SAŽETAK
$\mathrm{Na}$ osnovi poznavanja dimenzijskih značajki skidera s vitlom (osnovne dimenzije, masa vozila, položaj točke težišta), razvijen je model procjene kretnosti skidera za privlačenje drva uz nagib terena na siguran, djelotvoran i okolišno prihvatljiv način. Model je zasnovan na graničnom nagibu kretnosti skidera temeljem vučne značajke vozila, koji povezuje dva istraživačka pristupa, 1 ) vozilo - teren (raspodjela sila ovisno nagibu i vučenom teretu) te 2) kotač - tlo (procjena vučnih značajki skidera temeljem indeksa kotača), uz poštivanje niza ograničenja proisteklih iz prethodnih istraživanja: i) rasterećenja prednje osovine vozila, ii) preopterećenja stražnje osovine vozila, iii) najmanje uzdužne stabilnosti skidera, iv) najmanje nosivosti šumskog tla te v) dopuštenog opterećenja pneumatika.

Rezultati simulacijskog modeliranja procjene kretnosti skidera s vitlom Ecotrac $55 \mathrm{~V}$ opremljenoga pneumaticima 12.4-24 pri privlačenju drva uz nagib terena, značajno se razlikuju s obzirom na uvjete nosivosti podloge te masu vučenih tereta. Kod manjih tereta, mase do 1 tone, kretnost skidera određuju kriteriji/ograničenja graničnoga nagiba kretnosti vozila (vučna značajka) i okolišne pogodnosti (najmanja nosivost podloge). Porastom težine tereta, osim nosivosti šumskog tla, odlučujući ograničavajući čimbenik kretnosti postaje odnos opterećenja prednje i stražnje osovine vozila $(>1: 3,5)$, koji ograničava kretnost skidera na terene nagiba $<33 \%$ kod tereta od 1,5 tone, tj. $<20 \%$ kod tereta od 2 tone. Kod tereta od 2,5 tone, na kretnost skidera, utječu kriteriji najvećeg dopuštenog opterećenja stražnje osovine skidera na nagibima $<7 \%$.
\end{abstract}

KLJUČNE RIJEČI: skider s vitlom, privlačenje drva uz nagib, granični nagib kretnosti skidera, vučna značajka

\section{UVOD}

\section{INTRODUCTION}

Pri ocjenjivanju pogodnosti primjene šumskih vozila koje rabimo za sječu i izradbu te privlačenja drva, ali i planiranje izvođenja mehaniziranog pridobivanja drva na djelotvoran, siguran i okolišno prihvatljiv način, pred šumarske se stručnjake nameće zahtjev za poznavanjem kretnosti šumskih vozila (Đuka 2014, Eichrodt i Heinimann 2001, Holzfeind i dr. 2019, Labelle i Lemmer 2019, Marčeta i dr. 2020).
Kretnost je šumskih vozila njihova sposobnost prolaska s jednoga na drugo mjesto u prostoru šumskoga radilišta (sječine) uz zadržavanje: 1) mogućnosti izvršavanja svoje primarne zadaće i 2) okolišne i energijske pogodnosti. Prisutnost i izraženost terenskih čimbenika (nagib terena, površinske prepreke i nosivost podloge), određuje prometnost terena, koja omogućuje ili onemogućuje kretanje šumskih vozila (Poršinsky i dr. 2016). S obzirom na složenost međudjelovanja vozila i terena, isti autori raščlanjuju kretnost

\footnotetext{
1 Prof. dr. sc. Tomislav Poršinsky, e-pošta: tomislav.porsinsky@sumfak.unizg.hr, Doc. dr. sc. Andreja Đuka, e-pošta: andreja.duka@sumfak.unizg.hr, Zavod za šumarske tehnike i tehnologije, Sveučilište u Zagrebu, Fakultet šumarstva i drvne industrije, Svetošimunska 25, HR - 10000 Zagreb

${ }^{2}$ Dr. sc. Željko Tomašić, e-pošta: zeljko.tomasic@hrsume.hr, Hrvatske šume d.o.o. - Direkcija Zagreb, Ulica kneza Branimira 1, HR - 10 000 Zagreb, Vitomir Kajgana, mag. ing. silv., auric forest d.o.0., Vatroslava Lisinskog 65, 31500 Našice, e-mail: vkajgana@auric-oak.com

* dopisni autor - corresponding author
} 
A) Pristup vozilo (skider s vitlom) - teren - Vehicle (cable skidder) - terrain approach

$F_{0}=F_{01}+F_{02}+\ldots$

$F_{1}=F_{11}+F_{12}+\ldots$

$F_{0}=F_{1}+F_{v}$

$F_{0}=G f \cos \alpha+G \sin \alpha+k Q f \cos \alpha+k Q \sin \alpha+(1-k) Q \mu_{p} \cos \alpha+(1-k) Q \sin \alpha$

Izvor - Source: Poršinsky i dr. (2012)

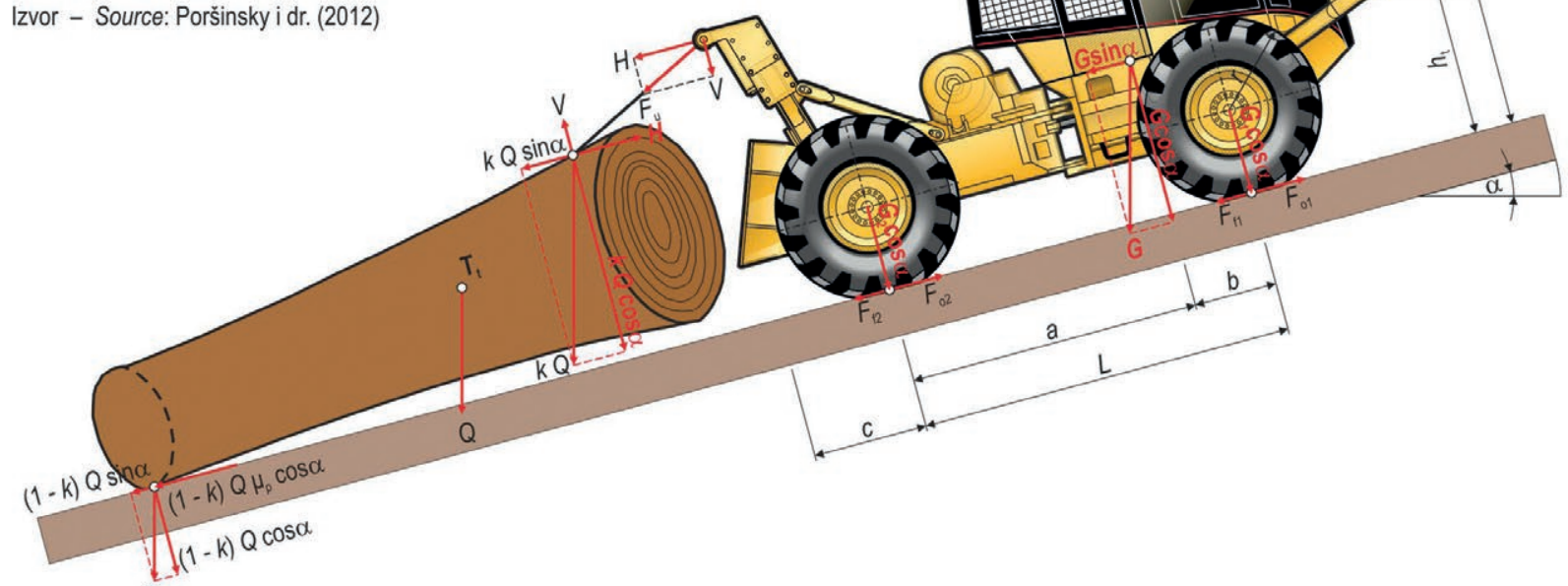

$(1-k) Q$

Kazalo oznaka - Labels:

$\alpha$ Kut uzdužnoga nagiba terena

Angle of longitudinal terrain slope

H Horizontalna komponenta sile u užetu Horizontal component of rope force

$G$ Težina skidera

Skidder weight

$G$, Opterećenje prednje osovine

Front axle load

$\checkmark$ Vertikalna komponenta sile u užetu Vertical component of rope force

Q Težina tereta Load weight

$G_{2}$ Opterećenje stražnje osovine

$f$ Faktor otpora kotrljanja Rolling resistance factor

F. Obodna sila

k Faktor raspodjele mase tereta

Thrust force

Load mass distribution factor

$F_{u}$ Sila u užetu

Rope force

$\mu_{\mathrm{p}}$ Faktor otpora privlačenja drva Skidding resistance factor

L Međuosovinski razmak Wheelbase

a Udaljenost težišta od stražnje osovine Center of gravity distance from rear axle

b Udaljenost težišta skidera od prednje osovine Center of gravity distance from front axle

$h$. Visina težišta skidera Center of gravity height

c Udaljenost horizontalnih valjaka od stražnje osovine Horizontal rollers distance from rear axle

d Visina horizontalnih valjaka Horizontal rollers height

B) Pristup kotač - tlo - Wheel - soil approach
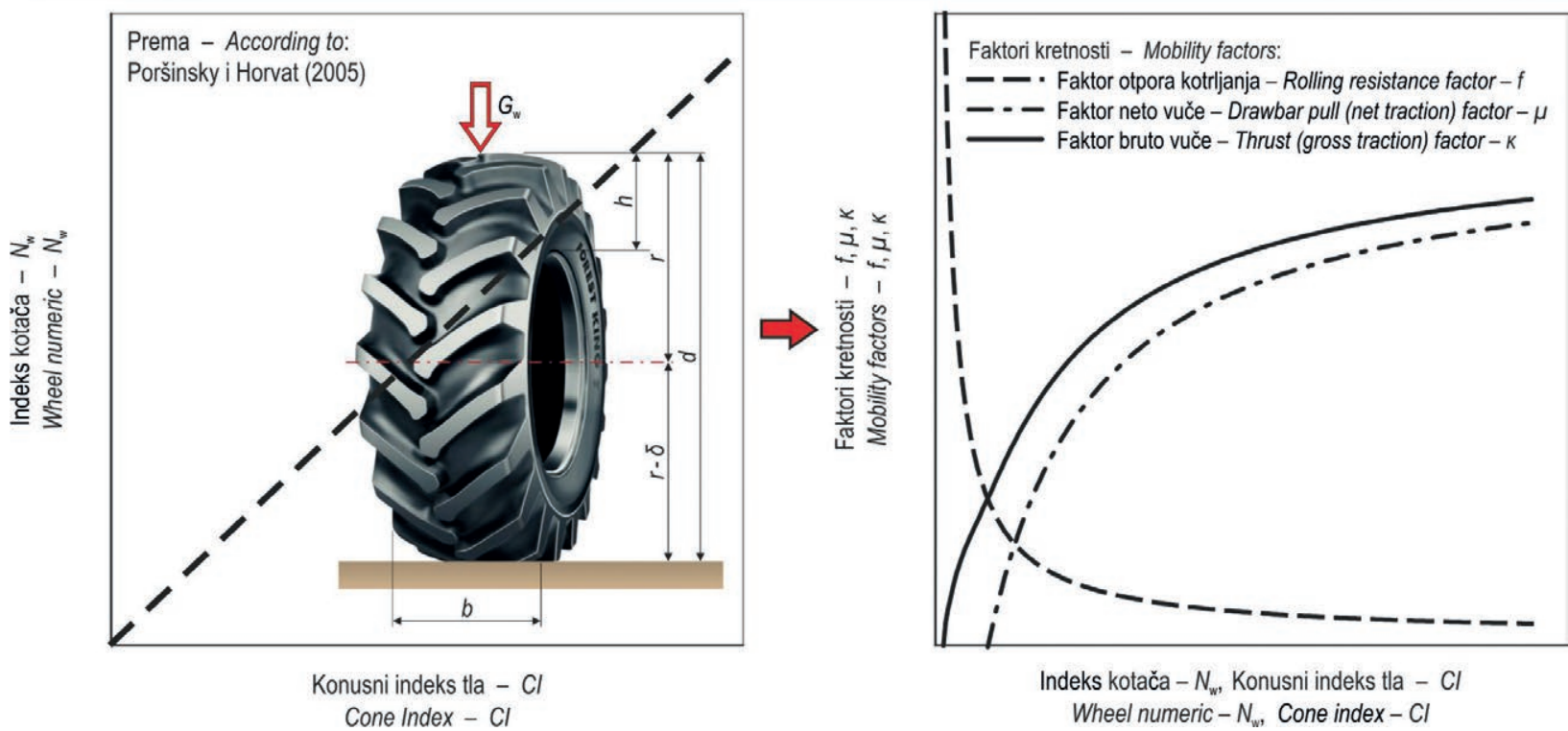

Slika 1. Pristupi istraživanju kretnosti skidera s vitlom

Fig. 1 Research approach of cable skidder mobility

šumskih vozila na: 1) Prohodnost (mogućnost svladavanja nepravilnosti terena, pri čemu dolazi do međudjelovanja dva geometrijska sustava - geometrije vozila i geometrije površine terena), 2) Vučnu značajku (ovisnost vučne sile o klizanju kotača i nosivosti podloge) te 3) Okolišnu (dodirni tlakovi) i energijsku (potrošnja goriva) pogodnost. Đuka 
(2014) ističe da je odabir sredstva privlačenja drva u svjetlu djelovanja terenskih čimbenika određenih reljefnih područja šuma te razine primarne i sekundarne otvorenosti šuma, najbitnija odrednica cijeloga sustava pridobivanja drva.

Šumska vozila za privlačenje drva, međusobno se razlikuju s obzirom na različitost načina prihvata drva (vučno uže ili hidraulična dizalica), pogodnih metoda izradbe drva (stablovna, deblovna ili sortimentna), načina kretanja drva u odnosu na dodir s tlom (vuča po tlu ili koturanje na kotaču), područja primjene (ravničarsko-brežuljkasti ili nagnuti tereni) te se njihova kretnost može opisati na primjerima dva dijametralno suprotna vozila: forvarderu i skideru. Svakako, skider s vitlom predstavlja veći istraživački izazov uslijed zahtijevnijega međudjelovanja s terenom, ali i zbog značajno većega udjela privučenoga drva u hrvatskome šumarstvu (Tomašić 2012).

Pored udaljenosti privlačenja drva (Đuka i dr. 2017), najznačajniji utjecajni čimbenik proizvodnosti i jediničnih troškova privlačenja drva je obujam tereta (drva), koji šumska vozila transportiraju unutar traktorskog turnusa (ciklusa). Najčešće je pitanje koje se postavlja pri odabiru vozila, ali i planiranju privlačenja drva: Koji teret može određeno šumsko vozilo privući na određenom nagibu i smjeru nagiba terena te pri određenoj nosivosti podloge?

Odgovor na postavljeno pitanje nije jednostavan, jer se privlačenje drva skiderima odvija s jednim krajem vučenoga drva odignutim od tla te preko vučnog uža vitla ovješenim i/ili oslonjenim na stražnju zaštitno-prihvatnu dasku vozila, dok se drugi oslonjeni kraj tereta vuče po tlu, iz čega proizlazi osnovna namjena skidera - ostvarivanje vučne sile na obodu kotača. Mjerenja cijeloga niza sila, otpora i momenata, dugotrajan su i skup postupak, a polučeni su rezultati mjerenja primjenjivi isključivo na uvjete u kojima su mjerenja vršena (tip skidera, uzdužni nagib terena, smjer privlačenja drva, nosivost šumskog tla, značajke vučenoga drva).

Odgovor na postavljeno pitanje daje simulacijsko modeliranje koje povezuje dva istraživačka pristupa proučavanju procjene kretnosti skidera pri privlačenju drva (slika 1), a kojim je moguće obuhvatiti širi raspon vrijednosti navedenih utjecajnih čimbenika, uz poštivanje ograničenja koja su proistekla iz prethodnih istraživanja.

Teorijski pristup/okvir raspodjele sila pri privlačenju drva skiderom s vitlom, postavio je Bennet (1962) koji je raščlanio sile pri privlačenju drva na vertikalne, horizontalne i frikcijske, a koji je u literaturi postao poznat pod nazivom "sustav vozilo - teren«. Navedenim, skider pri privlačenju drva po ravnome terenu, započinje vuču drva u trenutku kada obodna sila (dovedena sustavom transmisije na obod kotača vozila) započinje svladavati sile otpora: 1) kotrljanja skidera, 2) kotrljanja dijela ovješenoga tereta o vučno uže i
3) trenja dijela oslonjenog tereta (drva) na šumsko tlo. Pri privlačenju drva uz nagib terena, raspodjela sila postaje složenija te skider započinje vuču drva u trenutku kada obodna sila započinje svladavati još i otpore sila (slika 1A): 1) svladavanja nagiba terena skiderom, 2) svladavanja nagiba terena dijela ovješenog tereta te 3 ) svladavanja nagiba terena dijela oslonjenog tereta. Pri privlačenju drva niz nagib terena, obodna sila savladava iste otpore kao i kod privlačenja drva uz nagib, samo rezultante tri sile otpora (otpor svladavanja nagiba terena skiderom, otpor svladavanja nagiba terena dijela ovješenog tereta, otpor svladavanja nagiba terena dijela oslonjenog tereta) sada djeluju u suprotnome smjeru, tj. smjeru kretanja vozila. Upravo iz sustava »vozilo - teren «, proizlazi i jedino ograničenje privlačenje drva niz nagib terena - granični nagib terena pri kojem vučeno drvo počinje gurati skider, tj. trenutak kada horizontalna sastavnica sile u užetu poprimi vrijednost nula, što se događa kada su težina tereta i otpor vuče u ravnoteži (Đuka 2014, Đuka i dr. 2016).

Osim dimenzijskih i masenih značajki vozila, teorijski pristup "vozilo - teren« istraživanja privlačenja drva skiderom, zahtijeva poznavanje faktora raspodjele tereta i otpora privlačenja drva (Hassan 1977, Sever 1980). Faktor raspodjele mase tereta pokazuje kolika je masa tereta odignuta od tla, odnosno ovješena o uže, a kolika se vuče oslonjena na tlo. Značenje faktora raspodjele mase tereta na privlačenje drva ogleda se u nastojanju da se što veći dio tereta (vučenoga drva) odigne od tla kako bi se povećala adhezijska težina vozila, smanjilo oštećenje tla, ali i smanjila vučna sila potrebna za svladavanje otpora privlačenja (Horvat 1990). Dosadašnja su istraživanja (Hassan i Sirois 1983) pokazala da faktor raspodjele mase tereta ne ovisi samo o dimenzijama (masi) tereta, već i o visini hvatišta sile u užetu kojim je teret pričvršćen za skider. Zbog vuče po tlu dijela tovara javlja se otpor privlačenja određen težinom tereta oslonjenoga na tlo i faktorom otpora privlačenja. Horizonatalna sastavnica sile u užetu svladava otpore privlačenja između dijela težine tereta i tla te se stoga na osnovi poznatih vrijednosti sile, težine i faktora raspodjele mase tereta te nagiba terena izračunava faktor otpora privlačenja (Poršinsky i dr. 2012). Faktor otpora privlačenja osim o težini tereta ovisi o obliku tereta, veličini dodirne površine tereta s tlom i neravninama podloge (Hassan i Gustafson 1983). Isti autori, navode da se oblik tereta razlikuje s obzirom na metodu izrade (stablovna, deblovna, sortimentna), a veličina dodirne površine između tovara vučenoga drva i tla ovisi o visini vezanja tereta, orijentaciji vuče (deblji ili tanji kraj) te broju komada stabala/debala/oblovine u teretu. Porastom točke vezanja tereta smanjuje se dodirna površina tereta s tlom i otpor privlačenja. U dosadašnjim istraživanjima vučnih značajki skidera utvrđene su sljedeće prosječne vrijednosti faktora raspodjele mase tereta 0,462 $\pm 0,118$ (Kockums 821, Sever 1980), 0,485 $\pm 0,093$ (Ecotrac 
$120 \mathrm{~V}$, Šušnjar 2005), 0,527 $\pm 0,065$ (Ecotrac 55V, Tomašić 2007), odnosno faktora otpora privlačenja drva $0,442 \pm$ 0,120 (Kockums 821, Sever 1980), 0,485 \pm 0,093 (Ecotrac $120 \mathrm{~V}$, Šušnjar 2005) te 0,549 $\pm 0,103$ (Ecotrac 55V, Tomašić 2007).

Kretnost skidera ovisi i o njegovim vučnim značajkama tj. ovisnosti vučne sile o klizanju kotača i nosivosti podloge (Hassan 1977, Horvat 1990, Sever 1980). Razvojem empirijske metode proučavanja složenoga sustava kotač - tlo, u literaturi poznate kao WES - metoda (Waterways Experimentation Station, US Army Corps of Engineering Research), za povezivanje vučnih značajki vozila s nosivosti tla (konusnim indeksom) koristi se - indeks kotača (slika 1B). Indeks kotača predstavlja bezdimenzijski parametar (faktor), koji opisuje međudjelovanje opterećenoga kotača i tla. Ovaj je pokazatelj određen odnosom dodirnoga tlaka kotača na tlo i nosivosti tla mjerene penetrometrom. Pomoću faktora kretnosti (bruto i neto vuče, otpora kotrljanja) izražavaju se i procjenjuju vučne značajke vozila (obodna i vučna sila, otpor kotrljanja) na osnovi opterećenja kotača vozila (slika 1B). Područje iznad krivulje faktora bruto vuče je područje nemogućega kretanja vozila, jer je u tom slučaju optereće-
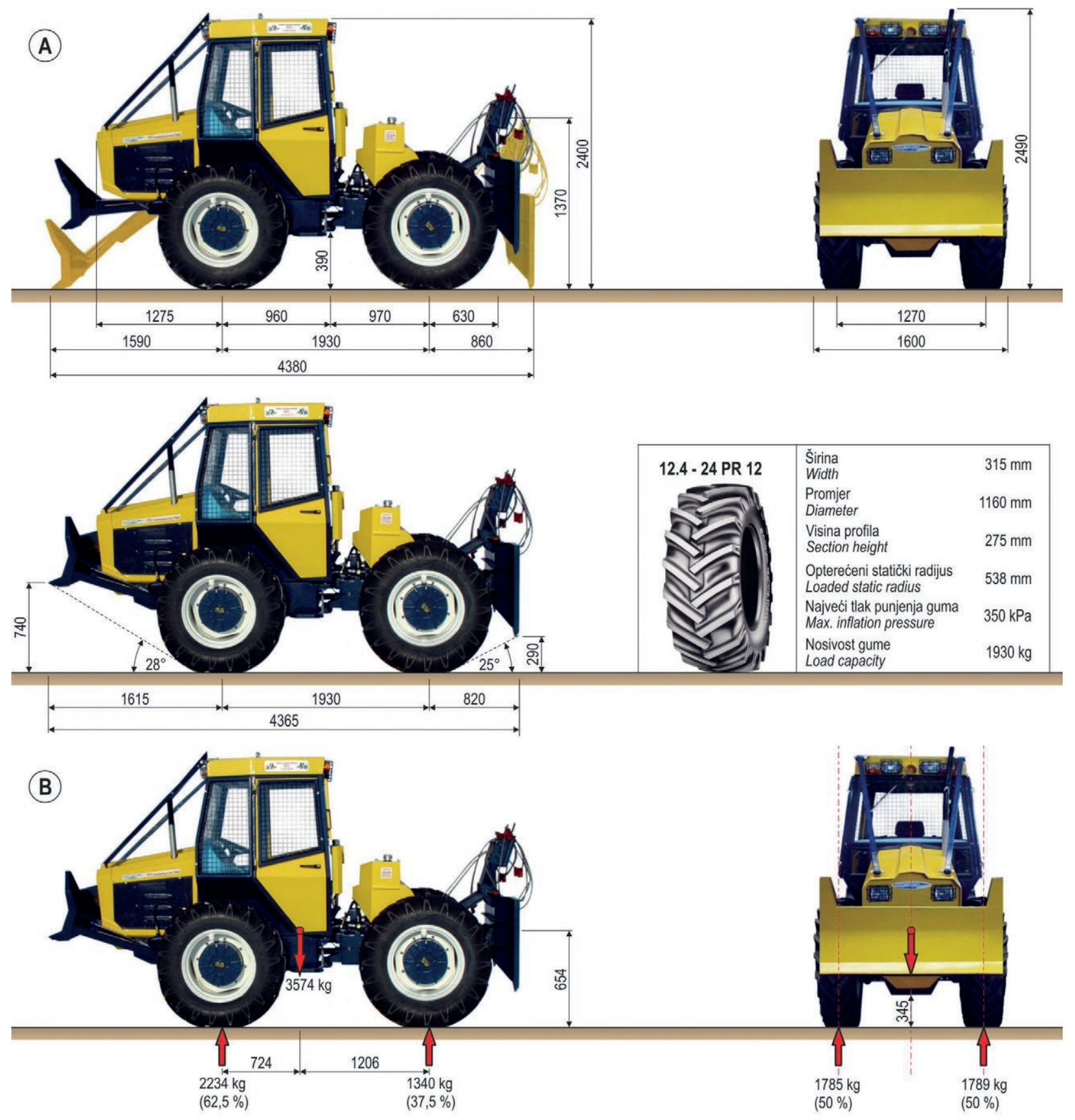

Prema - According to: Tomašić (2007) i Kajgana (2014)

Slika 2. Skider s vitlom Ecotrac 55V (A - Dimenzije vozila i značajke guma, B - Raspodjela mase)

Fig. 2 Ecotrac 55V Cable Skidder (A - Vehicle dimensions and tyre characteristics, B - Mass distribution) 
nje kotača veće od obodne sile. Poršinsky i Horvat (2005) navode da faktor neto vuče pokazuje koliko se adhezijske težine šumskih vozila pretvara u vučnu silu. Skideri počinju ostvarivati vuču tereta u sjecištu krivulja faktora neto vuče i otpora kotrljanja, a forvarderi u sjecištu krivulja faktora bruto vuče i otpora kotrljanja zato što ne vuku drvo već ga voze (nose) na sebi te pri tome svladavaju samo otpore kotrljanja (Poršinsky 2005). Isti autor, navodi da u slučaju različitih dimenzija prednjih i stražnjih kotača, odnosno nejednake raspodjele opterećenja između prednje i stražnje osovine vozila, za procjenu se kretnosti vozila po WES-metodi koristi tzv. referentni kotač - kotač vozila, kao onaj s najnižom vrijednošću indeksa kotača, odnosno najvećim opterećenjem kotača vozila.

Cilj je ovoga rada, na primjeru prorednoga skidera s vitlom Ecotrac 55V, odrediti: 1) granični nagib kretnosti skidera temeljem vučne značajke vozila s obzirom na različite veličine tovara vučenoga drva i uvjete nosivosti podloge, odnosno 2) model procjene kretnosti skidera pri privlačenju drva uz nagib terena.

\section{MATERIJAL I METODE MATERIALS AND METHODS}

Izrada modela procjene kretnosti skidera za privlačenje drva uz nagib, zasnovana je na šumskom vozilu hrvatske strojogradnje Ecotrac 55V. Skider Ecotrac 55V je četverokotačno zglobno vozilo (pogona $4 \times 4$ ) opremljeno dvobubanjskim šumskim vitlom Hittner $2 \times 35$, nazivne vučne sile $35 \mathrm{kN}$. Skider je pogonjen dizelskim motorom DEUTZ, zapremine $3236 \mathrm{~cm}^{3}$, nazivne snage $40 \mathrm{~kW}$ pri $2300 \mathrm{~min}^{-1}$ te najvećega zakretnoga momenta od $207 \mathrm{Nm}$ pri $1600 \mathrm{~min}^{-1}$. Osim male mase (3,574 t) te 3,9 m unutarnjeg i 4,2 m vanjskog polumjera skretanja, posebnost je ovoga prorednoga skidera izostanak prednje oscilirajuće osovine, a vertikalnu gibljivost okvira vozila osigurava dvosmjerni (forvarderski) zglob s kutom loma u vertikalnoj ravnini od $16^{\circ}$. Osnovne tehničke značajke skidera Ecotrac 55V, s obzirom na normu ISO 13861 (2000), prikazane su na slici 2.

$\mathrm{Na}$ temelju gabaritnih dimenzija skidera Ecotrac 55V (slika $2 \mathrm{~A}$ ) te poznavanja mase i položaja točke težišta vozila (slika 2B) odredit će se raspodjela opterećenja skidera pri privlačenju drva uz nagib terena s obzirom na različitu količinu (masu) vučenog drva. Za potrebne ovisnosti faktora raspodjele tereta (izraz 9) i otpora privlačenja drva (izraz 10) skiderom Ecotrac 55V o utjecajnim čimbenicima, koristiti će se stohastički izrazi koje je utvrdio Kajgana (2014) naknadno obrađujući izvorne podatke mjerenja vučnih značajki skidera Ecotrac 55V (Tomašić 2007).

Raspodjela opterećenja skidera Ecotrac 55V, obuhvatit će izračun i analize sljedećih parametara: 1) Adhezijske težine skidera (izraz 1), 2) Okomite (vertikalne) sastavnice sile u užetu (izraz 3), 3) Usporedne (horizontalne) sastavnice sile u užetu (izraz 4), 4) Opterećenja prednje osovine skidera (izraz 5), 5) Opterećenja stražnje osovine skidera (izraz 6), 6) Graničnog tereta prema uzdužnoj stabilnosti vozila (izraz 7), 7) Vučne sile (izraz 2) te 8) Faktora neto vuče (izraz 8). Opterećenje kotača skidera $\left(G_{w}\right)$, ovisno o uzdužnom nagibu terena te količini (masi) vučenoga drva, pretpostavit će podjednaku raspodjelu osovinskog opterećenja. Na osnovi opterećenja kotača skidera, utvrdit će se referentni kotač vozila (kao onaj s najvećim opterećenjem), ali i izračunati nominalni tlak skidera na podlogu (Mellgren 1980), prema izrazu 15.

Procjena vučnih značajki skidera Ecotrac 55V odredit će se temeljem Briuxiusovog modela (Brixius 1987), s obzirom na: 1) opterećenje referentnog kotača vozila, 2) konusni indeks tla, 3) klizanje kotača od $20 \%$. Brixiusov model kretnosti vozila zasnovan je na izrazima: 1) indeksa kotača vozila (izraz 11), 2) faktora otpora kotrljanja (izraz 12) te 3) faktora bruto vuče (izraz 13). Navedeni izrazi koji predviđaju vrijednosti indeksa kotača i faktora kretnosti razvijeni su regresijskom analizom mjernih rezultata 121 pokusa, tj. kombinacije tla i dimenzija guma, odnosno opterećenja kotača. S obzirom na to da je indeks kotača temeljen i na progibu pneumatika kotača, za procjenu ovoga parametra korišten je empirijski izraz (Saarilahti 2002), koji se zasniva na tlaku punjenja guma i opterećenju kotača (izraz 14). Posebno valja istaknuti, da iako je Brixsiusov model razvijen za potrebe procjene kretnosti poljoprivrednih traktora po oranicama, mnogi autori (Eichrodt 2003, Lubello 2008, Đuka 2014) ga smatraju najpogodnijim za procjenu kretnosti šumskih vozila, uslijed uklapanja značajki opterećenih šumskih vozila u područje primjenjivosti modela.

U odnosu na ostale autore, Brixsiusov indeks kotača (izraz 11), u obzir uzima i: 1) omjer progiba i visine profila gume $(\Delta / h)$ te 2$)$ omjer širine i promjera gume (b/d) opterećenoga kotača. Indeks kotača, koji predstavlja međudjelovanje opterećenoga kotača i tla, koristi se u jednadžbama za predviđanje faktora otpora kotrljanja (izraz 12) i faktora bruto vuče (izraz 13). Posebno valja istaknuti da Brixiusov model

\footnotetext{
Pojava klizanja predstavlja smicanje čestica tla zahvaćenog rebrima pneumatika koja se zasjecaju u tlo pri kontaktu s njegovim površinskim slojem. Pri manjim vučnim silama površinski sloj tla po kojem se kreću pogonski kotači skidera ostaje na svom mjestu, jer je vučna sila traktora manja od kohezijskih sila tla. Proklizavanje kotača nastupa u trenutku kada dolazi do prekoračenja otpora tla na smicanje zahvaćenog rebrima kotača uslijed povećane vlažnosti tla. Samo klizanje kao pojava, ne ograničava potrebnu obodnu odnosno vučnu silu, već predstavlja energijski gubitak koji smanjuje brzinu kretanja vozila i utječe na korisnost kotača. Šušnjar i dr. (2010) navode da se najveća korisnost kotača pri privlačenju drva šumskim vozilima postiže kod klizanja $20 \%$, a daljim porastom klizanja dolazi do strmog pada faktora bruto vuče i rasta faktora otpora kotrljanja.
} 
Tablica 1. Jednadžbe korištene u određivanju pokazatelja privlačenja drva skiderom s vitlom Table 1 Equations used in defining parameters during timber extraction with a cable skidder

Pristup vozilo (skider s vitlom) - teren (privlačenje drva uz nagib terena) - Vehicle (cable skidder) - terrain (uphill timber extraction) approach

Adhezijska težina - Adhesive weight [kN]

$G_{\mathrm{a}}=G \cos \alpha+V$

Okomita sastavnica sile u užetu - Vertical component of rope force [kN]

$V=k 0 \cos \alpha$

Opterećenje prednje osovine - Front axle load [kN]

$G_{1}=\frac{G \cos \alpha a-G \sin \alpha h_{\mathrm{t}}-H d-V c}{L}$

Granični teret prema uzdužnoj stabilnosti vozila - Critical load in reference to vehicle longitudinal stability [kN]

$O_{\text {crit }}=\frac{G\left(a \cos \alpha-h_{\mathrm{t}} \sin \alpha\right)}{d \sin \alpha+k c \cos \alpha+d(1-k) \mu_{\mathrm{p}} \cos \alpha}$

Faktor neto vuče - Net traction factor

$\mu=\frac{F_{\mathrm{d}}}{G_{\mathrm{a}}}=\frac{H+G_{\mathrm{a}} \sin \alpha}{G_{\mathrm{a}}}$

Faktor raspodjele mase tereta - Load mass distribution factor $k=0,69028+0,00162 \alpha-0,05008 m-0,02816$ I

Faktor privlačenja - Skidding resistance factor

$\mu_{\mathrm{p}}=0,55136-0,00188 \alpha$

Kazalo simbola - Labels:

a - Udaljenost težišta od stražnje osovine - Distance from centre of gravity to rear axle [m]

$b$ - Udaljenost težišta od prednje osovine - Distance from centre of gravity to front axle [m]

$c$ - Udaljenost horizontalnih valjaka od stražnje osovine - Horizontal rollers distance from rear axle [m]

$d$ - Visina horizontalnih valjaka - Height of horizontal rollers [m]

$L$ - Međuosovinski razmak - Wheelbase [m]

$h_{\mathrm{t}}$ - Visina težišta - Centre of gravity height $[\mathrm{m}]$

$\alpha$ - Uzdužni nagib terena - Longitudinal terrain slope [\%]

G - Težina skidera - Skidder weight $[\mathrm{kN}]$

0 - Težina tereta - Load weight [kN]

$m$ - Masa tereta - Load mass [t]

I - Duljina tereta - Load length [m]

Pristup kotač - tlo - Wheel - soil approach

Indeks kotača - Wheel numeric

$N_{\mathrm{w}}=\left(\frac{C l b d}{G_{w}}\right)\left(\frac{1+5 \frac{\Delta}{h}}{1+3 \frac{b}{d}}\right)$

Faktor bruto vuče - Gross traction factor

$\kappa=0,88\left(1-e^{-0,1 N_{\mathrm{w}}}\right)\left(1-e^{-7,5 \delta}\right)$

Nominalni tlak na podlogu - Nominal ground pressure [kPa]

$N G P=\frac{G_{\mathrm{w}}}{r b}$

Kazalo simbola - Labels:

$\mathrm{Cl}$ - Konusni indeks tla - Cone indeks [kPa]

$G_{w}$ - Opterećenje referentnoga kotača - Referent wheel load [kN]

$\delta$ - Klizanje kotača - Wheel slip [\%]

$r$ - Polumjer pneumatika - Tyre radius [m]

$p_{\mathrm{i}}$ - Tlak zraka u pneumatiku - Tyre inflation pressure $[\mathrm{kPa}]$
Faktor otpora kotrljanja - Rolling resistance factor

$f=\frac{1,0}{N_{\mathrm{w}}}+0,04+\frac{0,5 \delta}{\sqrt{N_{\mathrm{w}}}}$

Progib pneumatika - Tyre deflection [m]

$\Delta=0,008+0,01\left[0,365+\left(\frac{170}{p_{\mathrm{i}}}\right)\right] G_{\mathrm{w}}$

Najmanji konusni indeks - Minimal soil bearing capacity [kPa]

$C I_{\min }=7,2 \mathrm{NGP}$

$b$ - Širina pneumatika - Tyre width [m]

$d$ - Promjer pneumatika - Tyre diameter [m]

$h$ - Visina presjeka pneumatika - Tyre section height [m]

$\Delta$ - Progib pneumatika - Tyre deflection [m] ne obuhvaća izraz faktora neto vuče, već je izražen kao razlika faktora bruto vuče i faktora otpora kotrljanja.

Osnovne sastavnice Brixsiusova modela procjene bruto vuče, osiguravaju široku primjenu modela. Konstanta 0,88 ograničava najveći zakretni moment koji kotač postiže u doticaju s tlom do vrijednosti $0,92(0,88+0,04)$, koja se do- seže pri većim vrijednostima indeksa kotača, odnosno klizanja. Član modela $\mathrm{e}^{-0,1 N \mathrm{w}}$, kontrolira najveću vrijednost zakretnog momenta koji se postiže uz veće vrijednosti klizanja kotača. Indeks kotača, kao i zakretni moment, povećava se: 1) porastom konusnog indeksa $(C I), 2)$ porastom promjera $(d)$ ili širine (b) gume kotača, 3 ) smanjenjem op- 
terećenja kotača $\left.\left(G_{w}\right), 4\right)$ porastom omjera progiba i visine profila gume $(\Delta / h)$, te 5$)$ smanjenjem omjera širine i promjera gume $(b / d)$. U članu modela konstanta 7,5 , koja se naziva faktorom hrapavosti podloge, upravlja odnosom omjera zakretnog momenta i klizanja kotača.

Granični nagib terena pri privlačenju drva uz nagib temeljem vučne značajke zasnovan je na vrijednostima opterećenja referentnoga kotača pri različitim uzdužnim nagibima terena i vučenim teretima, kod kojih se izjednačavaju vrijednosti faktora neto vuče izračunatog na osnovi raspodjele opterećenja i Brixsiusovog modela, s ciljem utvrđivanja vrijednosti konusnoga indeksa tla (izraz 17). Na taj način, svakoj vrijednosti uzdužnoga nagiba terena pri vuči određene količine (mase) drva, pridružena je vrijednost najmanjega potrebnoga konusnoga indeksa tla da bi se skider mogao kretati.

$\frac{H+G_{\mathbf{a}} \sin \alpha}{G_{\mathbf{a}}}=$
$\left[0,88\left(1-e^{-0,1 N_{\mathbf{w}}}\right)\left(1-e^{-7,5 \delta}\right)\right]-\left[\frac{1,0}{N_{\mathbf{w}}}+0,04+\frac{0,5 \delta}{\sqrt{N_{\mathbf{w}}}}\right] \Rightarrow C I$

Predloženi model kretnosti skidera, poštivat će i ograničenja proizašla iz prethodnih istraživanja:

- Rasterećenja prednje osovine vozila (Weise i Nick 2003), gdje najmanje $10 \%$ ukupnog dinamičkog opterećenja treba ostati na prednjoj osovini $\left(G_{1}>0,1 G_{\mathrm{a}}\right)$, kako bi se omogućilo upravljanje vozilom;

- Preopterećenja stražnje osovine vozila (Horvat 1990), pri čemu opterećenje stražnjega mosta skidera ne smije prijeći ukupnu težinu skidera $\left(G_{2}<G\right)$;

- Najmanje uzdužne stabilnosti skidera (Sever 1980), koje je određeno najmanjim odnosom opterećenja prednje i stražnje osovine $\left(G_{1}: G_{2}>1: 3,5\right)$, nakon koje dolazi u pitanje uzdužna stabilnost vozila;

- Najmanje nosivosti šumskog tla (Wronsky i Humpreys 1994), zasnovane na smjernici privlačenja drva na okolišno prihvatljiv način (izraz 16),

- Dopuštenog opterećenja pneumatika kotača skidera, s obzirom na preporučeni tlak punjenja zrakom od strane proizvođača (Đuka 2014, Đuka 2018A, Poršinsky i dr. 2020).

\section{REZULTATI S RASPRAVOM RESULTS WITH DISCUSSION}

Raspodjela opterećenja skidera Ecotrac 55V, s obzirom na privlačenje drva uz nagib terena prikazana je za količinu vučenoga drva raspona mase od $0 \mathrm{t}$ (kretanje neopterećenoga vozila) do $2,5 \mathrm{t}$ (slika 3 ).
Uzdužna stabilnost vozila (slika 3A), kao jedan od kriterija kretnosti skidera nije ograničavajuće djelovala za analizirani raspon nagiba terena $(<50 \%)$ i raspona tereta, osim kod vuče tereta od 2,5 t uz nagib terena $>47 \%$. Promatrajući uzdužnu stabilnost vozila s obzirom na veće količine vučenoga drva (masa $>3 \mathrm{t}$ ) vidljivo je da će stabilnost biti narušena i pri nižim uzdužnim nagibima terena.

Na vučnu značajku skidera i raspodjelu sila pri privlačenju drva utječe odnos između ostvarenih sila na kotaču i sila koje se opiru njihovom djelovanju, pri čemu iznimno važnu ulogu ima adhezijska težina vozila (slika 3B). Pod adhezijskom se težinom $\left(G_{\mathrm{a}}\right)$ podrazumijeva zbroj okomitih opterećenja na pogonskim kotačima skidera pri vuči drva (slika $3 B)$. Adhezijska težina ovisi o težini skidera $(G)$, uzdužnome nagibu terena $(\alpha)$ te veličini vertikalne sastavnice sile u užetu $(V)$ na koju ponajprije utječe težina tereta $(Q)$ vučenoga drva. Adhezijska je težina različita od težine neopterećenoga skidera $(G)$ budući da se stražnji most dodatno opterećuje punim iznosom vertikalne sastavnice sile u užetu $(V)$, koja se raspoređuje na stražnje kotače preko horizontalnih valjaka vitla. Povećanje se adhezijske težine skidera ostvaruje odizanjem debljega kraja vučenoga drva od tla, što povećava vrijednost okomite sastavnice sile u užetu, uz smanjenje vrijednosti horizontalne sastavnice sile u užetu (Šušnjar i dr. 2010).

Razumijevanje dinamike raspodjele opterećenja po osovinama skidera s obzirom na težinu (masu) vučenoga drva i veličinu nagiba terena pri privlačenju drva uz nagib (slike 3B i 3C) teško je pojmiti bez shvaćanja djelovanja sile u užetu, odnosno njene okomite sastavnice $(V)$ koja služi za nošenje težine dijela tereta (drva) odignutog od tla, odnosno horizontalne sastavnice $(H)$ koja služi svladavanju otpora vuče dijela težine tereta oslonjenoga na tlo.

Pri privlačenju drva uz nagib, horizontalna sastavnica sile $\mathrm{u}$ užetu raste s porastom nagiba terena, odnosno veličinom tereta vučenoga drva (slika $4 \mathrm{~A}$ ), dok vertikalna sastavnica pokazuje znakovit porast samo s porastom veličine tereta (slika 4B), odnosno blagi pad porastom nagiba terena (uslijed smanjenja dijela tereta koji je nošen na užetu, tj. povećava se dio težine tereta koji se oslanja na tlo). Pri vuči drva uz nagib, horizontalna je sastavnica sile u užetu veća od vertikalne, kod tereta mase: $0,5 \mathrm{t}$ kod nagiba $>46 \%, 1 \mathrm{t} \mathrm{kod}$ nagiba $>40 \%, 1,5 \mathrm{t}$ kod nagiba $>35 \%, 2 \mathrm{t}$ kod nagiba $>29$ $\%$ te 2,5 tone kod nagiba $>23 \%$.

Povećanjem nagiba terena, ali i mase tereta vučenoga drva pri privlačenju drva uz nagib, dolazi do rasterećenja prednje osovine skidera (slika 3C), odnosno porasta opterećenja stražnje osovine skidera (slika 3D) zbog: 1) rasta usporedne sastavnice težine skidera ( $G \sin$ a) koja djeluje suprotno od smjera kretanja vozila te 2 ) rasta horizontalne (usporedne) sastavnice sile u užetu. 

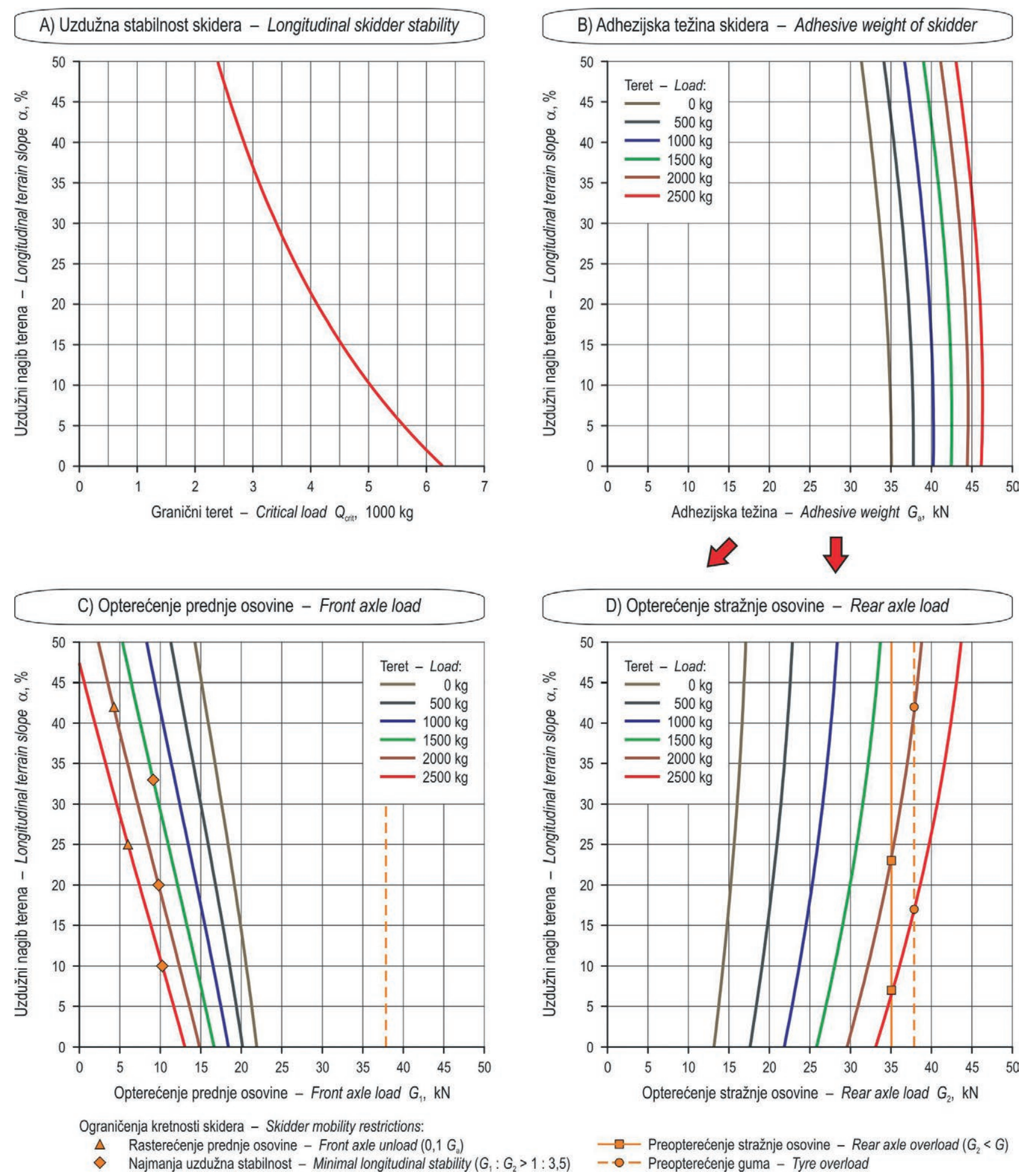

Ograničenja kretnosti skidera - Skidder mobility restrictions:

$\Delta \quad$ Rasterećenje prednje osovine - Front axle unload $\left(0,1 G_{a}\right)$

$\diamond$ Najmanja uzdužna stabilnost - Minimal longitudinal stability $\left(G_{1}: G_{2}>1: 3,5\right)$

- Preopterećenje stražnje osovine - Rear axle overload $\left(G_{2}<G\right)$

- $\bullet-$ Preopterećenje guma - Tyre overload

Slika 3. Utjecaj nagiba na granični teret, adhezijsku težinu i njenu raspodjelu po osovinama skidera

Fig. 3 Slope influence on critical load, adhesion weight and its distribution on skidder axels

Provedena analiza ukazala je i na nagibe terena u kojima su opterećenja prednje i stražnje osovine skidera Ecotrac $55 \mathrm{~V}$ ovisno o težini (masi) vučenoga drva u ravnoteži (slika 3C i 3D). Taj trenutak se događa kod nagiba terena: $+37 \%$ pri kretanju neopterećenoga vozila, $+8 \%$ pri vuči tereta od $0,5 \mathrm{t}$, dok je kod vuče svih većih tereta od 1 tone pri privla- čenju drva uz nagib terena opterećenija stražnja osovina u odnosu na prednju osovinu skidera, što je vidljivo na slikama 3C i 3D na kojima su ucrtane i granice kretnosti skidera Ecotrac 55V, koje su proizašle iz prethodnih istraživanja: 1) rasterećenje prednje osovine vozila $\left.\left(\geq 10 \% G_{\mathrm{a}}\right), 2\right)$ najmanje uzdužne stabilnosti skidera $\left.\left(G_{1}: G_{2}>1: 3,5\right), 3\right)$ 

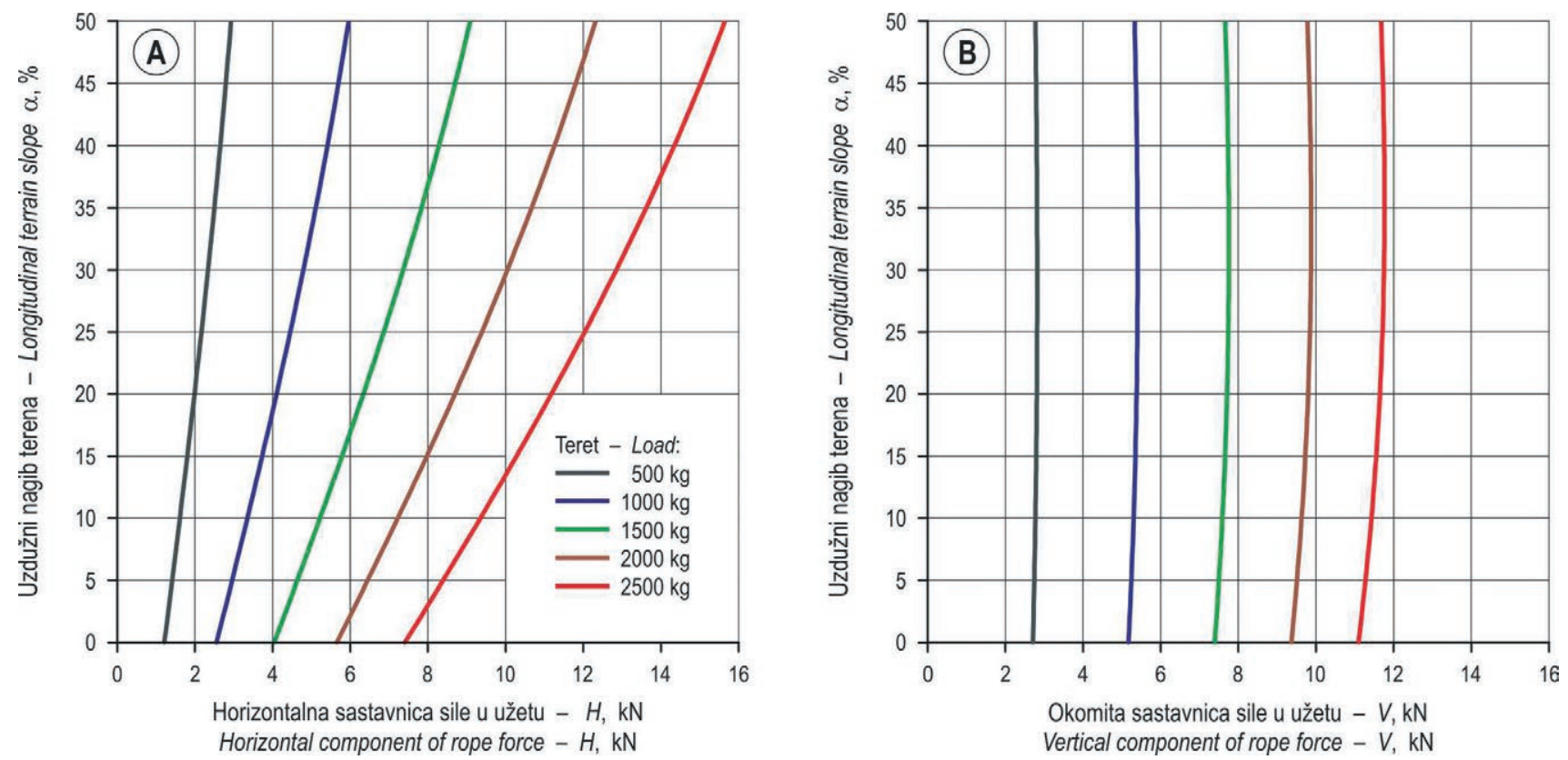

Slika 4. Utjecaj nagiba terena i količine vučenoga drva na horizontalnu i vertikalnu sastavnicu sile u užetu

Fig. 4 Load and slope influence on horizontal and vertical components of rope force

najveće opterećenje stražnje osovine skidera $\left(G_{2}<G, G=\right.$ $35,1 \mathrm{kN})$ te 4 ) dopušteno opterećenje guma 12.4-24 PR12 (1930 kg po gumi kotača pri tlaku punjenja guma zrakom od $350 \mathrm{kPa}$, odnosno 37,87 kN po osovini skidera). Navedeni kriteriji kretnosti skidera, različito su djelovali - ograničavali, područje rada skidera ovisno o nagibu terena i smjeru kretanja vozila, odnosno količini (masi) vučenoga drva.

Kriterij najmanje opterećenje prednje osovine skidera $\left(\geq 10 \% G_{a}\right)$, nije iskazao djelovanje kod tereta mase od 0 do
$1,5 \mathrm{t}$. Pri vuči tereta od $2 \mathrm{t}$ do rasterećenja prednje osovine skidera dolazi kod nagiba terena $>42 \%$ te tereta od $2,5 \mathrm{t}$ kod nagiba $>30 \%$.

Kriterij najmanja uzdužna stabilnost skidera $\left(G_{1}: G_{2}>1\right.$ : $3,5)$, nije iskazao djelovanje kod tereta od 0 i 0,5 tona. Pri vuči tereta od 1 tone pojavljuje se kod nagiba $>51 \%$, tereta od 1,5 tone kod nagiba $>33 \%$, tereta od 2 tone kod nagiba $>20 \%$ te kod tereta od 2,5 tone kod nagiba $>10 \%$.

Kriterij najveće opterećenje stražnje osovine skidera $\left(G_{2}<\right.$ $G)$, nije iskazao djelovanje kod tereta od 0 do 1,5 t. Pri vuči
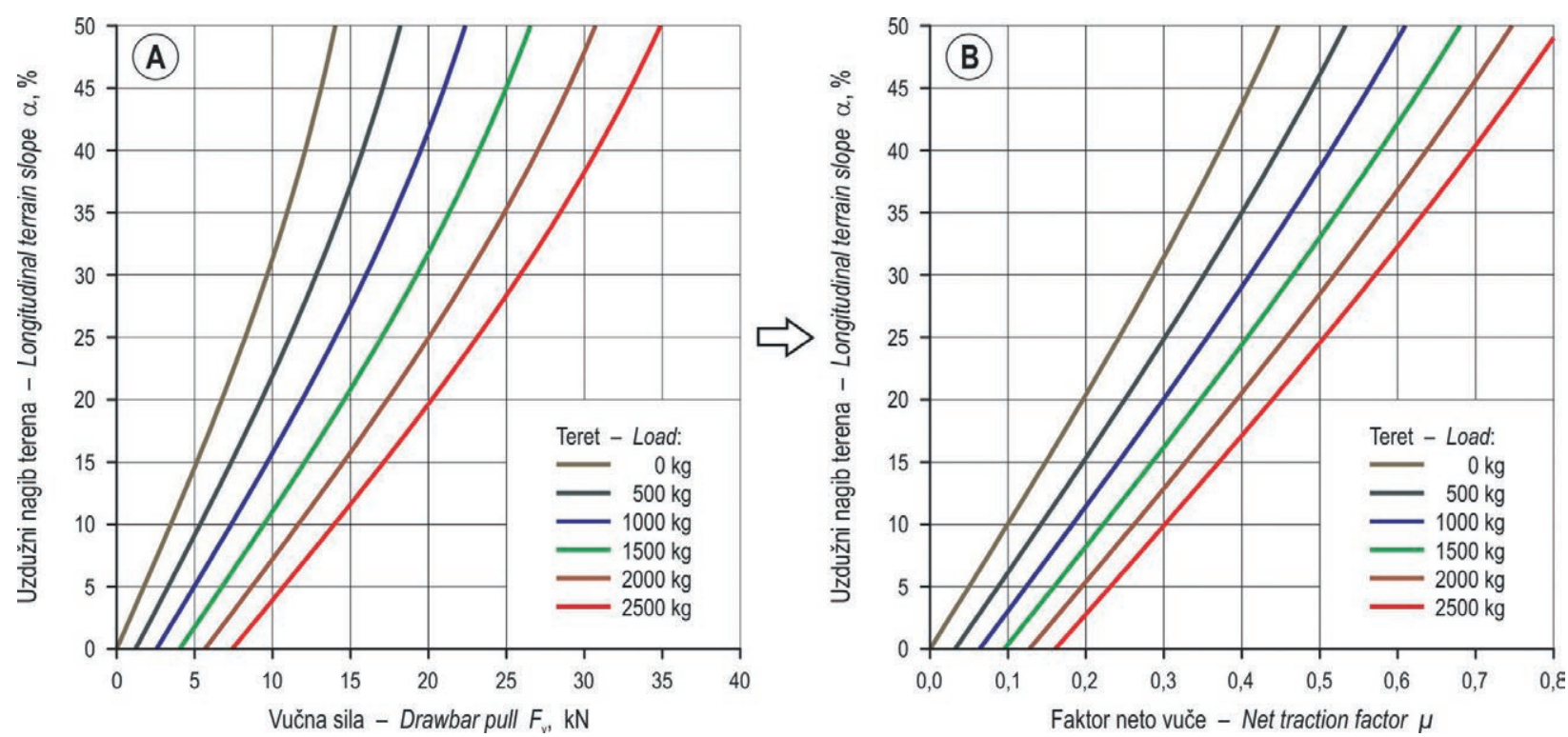

Slika 5. Utjecaj tereta i nagiba terena na vučnu silu te faktor neto vuče

Fig. 5 Load and slope influence on traction force and drawbar pull (net traction) factor 
tereta od $2 \mathrm{t}$ do preopterećenja stražnje osovine dolazi kod nagiba terena $>23 \%$, a tereta od 2,5 t kod nagiba $>7 \%$.

Kriterij najveće dopušteno opterećenje pneumatika 12.4-24 $(37,87 \mathrm{kN}$ po osovini), nije iskazao djelovanje kod tereta od 0 do $1,5 \mathrm{t}$. Pri vuči tereta od $2 \mathrm{t}$ do propterećenja guma kotača stražnje osovine skidera dolazi kod nagiba terena $>42 \%$ te tereta od $2,5 \mathrm{t}$ kod nagiba $>17 \%$.

Vučna se sila skidera koristi za svladavanje nagiba terena i vučnog otpora stvorenog na mjestu dodira tereta s tlom.
Dinamika raspodjele vučne sile skidera s obzirom na masu tereta i veličinu nagiba terena prikazana je na slici 5A.

Pri privlačenju uz nagib terena vučna sila treba svladati vučne otpore dijela tovara oslonjenog na tlo $(H)$, ali i otpor horizontalne sastavnice težine skidera $(G \sin \alpha)$ koja povlači vozilo niz nagib terena. $S$ rastom nagiba terena, brži je rast vučne sile s povećanjem mase vučenoga drva (slika $5 \mathrm{~A}$ ), uslijed povećanja vrijednosti horizontalnih sastavnica sile u užetu (vučnog otpora) i težine skidera koje vučna sila treba svladati.

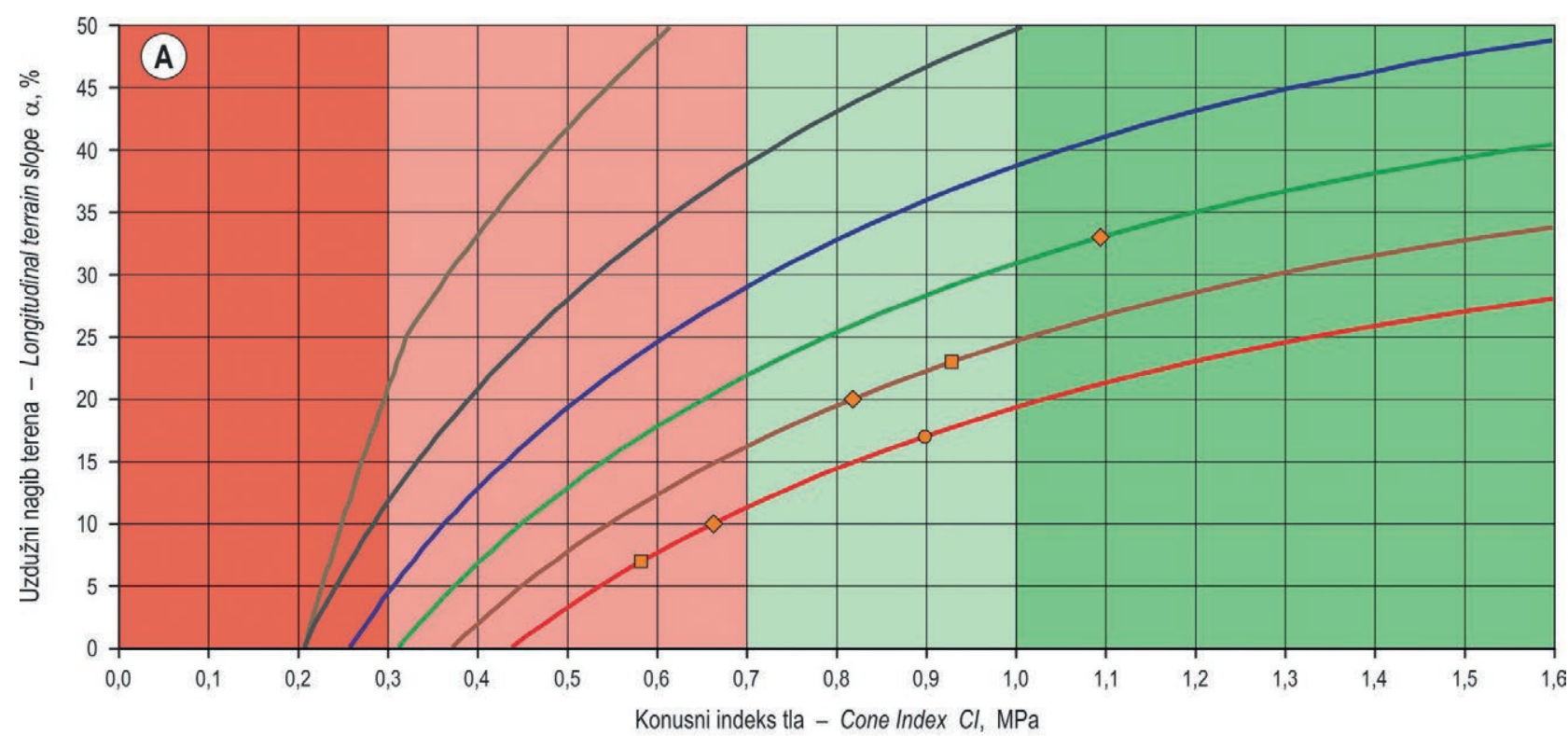

Razredba nosivosti tla - Soil bearing capacity classification:

Meko tlo - Soft soil $(300 \mathrm{kPa}<\mathrm{Cl}<700 \mathrm{kPa})$

Osrednje čvrsto tlo - Average strong soil $(700<\mathrm{Cl}<1000 \mathrm{kPa})$

Čvrsto tlo - Strong soil $(\mathrm{Cl}>1000 \mathrm{kPa})$

Izvor - Source: Bygden (2012)
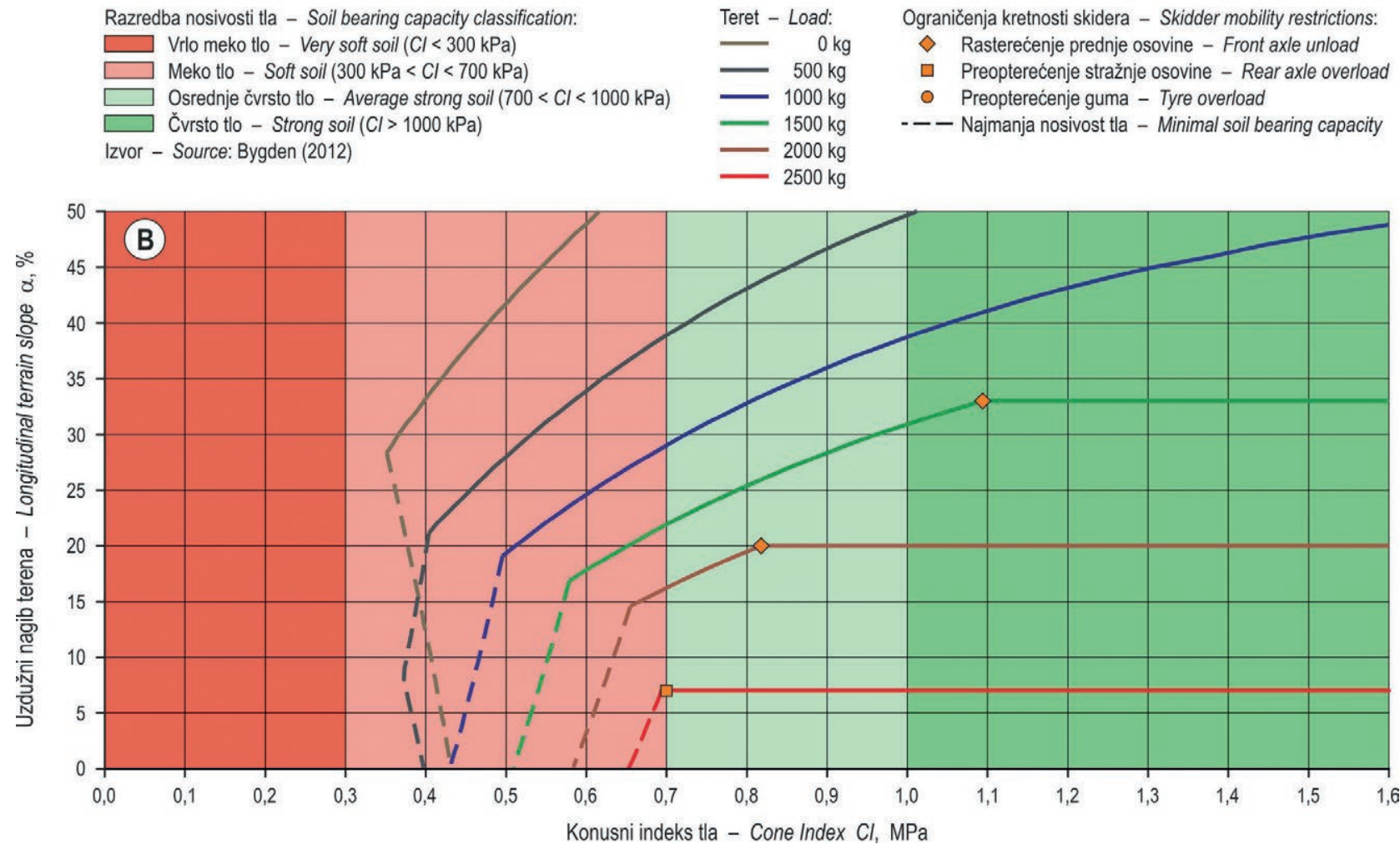

Slika 6. Granični nagib kretnosti vozila temeljem vučne značajke $(A)$ i raspon kretnosti skidera $(B)$

Fig. 6 Gredeability of the vehicle based on its traction performance $(A)$ and Skidder mobility range $(B)$ 
Na osnovi podaka dinamičke raspodjele vučne sile s obzirom na nagib terena i količinu (masu) vučenoga drva izračunate su vrijednosti faktora neto vuče (slika 5B) koji imaju isti tijek kao i vučna sila.

Unutar modela kretnosti skidera, rezultati simulacije raspodjele osovinskih opterećenja skidera (slike 3C i 3D), horizontalne (slika 4A) i vertikalne (slika 4B) sastavnice sile u užetu, vučne sile (slika 5A) i faktora neto vuče (slika 5B) u ovisnosti o nagibu terena i masi vučenoga drva su u skladu sa spoznajama rezultata prethodnih istraživanja (Horvat 1990, Sever 1980, Šušnjar 2005, Šušnjar i Horvat 2006, Tomašić 2007, Tomašić i dr. 2007, Tomašić i dr. 2009).

Na temelju podataka neto vuče za privlačenje drva uz nagib terena (slika 5B) i Brixsius-ovog modela procjene vučnih značajki za klizanje od $20 \%$ (najveća korisnost kotača uz najmanji otpor kotrljanja), povezana su dva pristupa kretnosti vozila: 1) vozilo - teren (raspodjela sila pri privlačenju drva) i 2) kotač - tlo (procjena vučnih značajki temeljem indeksa kotača). Na navedeni način izračunati su granični nagibi kretnosti vozila na temelju Brixsiusove vučne značajke za privlačenje drva uz nagib terena (slika 6A). Radi lakšega razumjevanja, na slici 6 vrijednosti konusnoga indeksa tla raščlanjeni su u četiri razreda nosivosti (vrlo meko tlo, meko tlo, osrednje čvrsto tlo, čvrsto tlo) šumskog tla (Bygden 2012). Za navedenu razredbu nosivosti tla, može se zaključiti da odgovara uvjetima hrvatskoga šumarstva što potvrđuju rezultati mjerenja konusnoga indeksa tla prethodnih istraživanja (Đuka 2014, Đuka i dr. 2018B, Poršinsky 2005, Poršinsky i dr. 2006, Šušnjar 2005, Tomašić 2007, Zorić i dr. 2018).

Granični nagib kretnosti skidera Ecotrac $55 \mathrm{~V}$ pri privlačenju drva uz nagib terena raste s porastom vrijednosti konusnoga indeksa tla (nosivosti tla), a za iste vrijednosti konusnoga indeksa tla opada s porastom mase (obujma) vučenoga drva (slika $6 \mathrm{~A}$ ). Za raspon nagiba terena $<50 \%$ te pri vuči tereta drva mase $<1 \mathrm{t}$, analiza graničnog nagiba kretnosti skidera Ecotrac 55V ukazala da je ograničena isključivo vučnom značajkom vozila i nosivošću podloge.

Ograničenja Severa (1980) te Weise i Nicka (2003) predstavljaju problem rasterećenja prednje osovine skidera pri privlačenju drva uz nagib terena, koji su autori predstavili sa različitim idejama (sa stajališta upravljivosti, odnosno uzdužne stabilnosti vozila). Analizirajući rezultate simulacije raspodjele osovinskih opterećenja (slika 3C, ali i 6A), uočljivo je da ograničenje Weise i Nicka (2003) nije značajno za privlačenje drva skiderom uz nagib terena jer je ograničenje Severa (1980) ukazalo djelovanje pri nižim nagibima terena, ovisno o masi vučenoga drva. Upravo najmanja uzdužna stabilnost skidera $\left(G_{1}: G_{2}>1: 3,5\right)$, na čvrstom tlu ograničila je privlačenje mase vučenog drva od 1,5 tona na nagib terena od $33 \%$, odnosno na osrednje čvrtom tlu privlačenje mase vučenog drva od 2 tone na nagib terena od $20 \%$.
Simulacija kretnosti skidera pri privlačenju drva mase $>2,5 \mathrm{t}$ uz nagib terena (slika $6 \mathrm{~A}$ ), ukazala je na djelovanje više ograničenja privlačenja drva: 1) preopterećenja stražnje osovine skidera (Horvat 1990) kod nagiba terena $>7 \%$, 2) najmanje uzdužne stabilnosti skidera (Sever 1980) kod nagiba terena $>10 \%$ te 3 ) dopuštenog opterećenje guma 12.4-24 PR12 (1930 kg po gumi kotača) kod nagiba terena $>17 \%$, čime je privlačenje ovakvih tereta uz nagib značajno ograničeno te se ne preporuča. Iz navedenoga, može se zaključiti da je sa stajališta kretnosti opremanje skidera Ecotrac 55V pneumaticima 12.4-24 PR12 dobro, a kriterij preopterećenja stražnje osovine skidera (Horvat 1990) svakako treba pojmiti kao glavni ograničavajući faktor privlačenja većih tereta drva skiderom uz nagib terena u cilju otklanjanja mogućih oštećivanja skidera u njihovome uporabnom ili amortizacijskom razdoblju. Svakako bi gume kotača skidera trebalo opremiti i lancima, čime bi se osiguralo klizanje kotača u optimalnim granicama (20\%), što bi se znakovito odrazilo na proizvodnost, smanjenje sabijanja tla, ali i smanjenje potrošnje goriva (Poršinsky i dr. 2020).

Najmanja nosivost šumskog tla (Wronsky i Humpreys 1994), kao ograničenje zasnovano na smjernici privlačenja drva na okolišno prihvatljiv način $\left(C I_{\min }>7,2 \mathrm{NGP}\right)$, jednostavno je utvrdljiv parametar na osnovi nominalnog tlaka referentnog kotača šumskog vozila (Poršinsky i dr. 2011), koji je pri opremanju skidera Ecotrac 55V standardnim gumama (12.4-24 PR12) ovisno o masi vučenoga drva, ukazao na najmanje vrijednosti konusnoga indeksa tla (slika 6B). Iako je granični nagib kretnosti skidera (slika 6A) ukazao na mogućnost privlačenja drva mase tovara $<1 \mathrm{t}$ na vrlo mekome tlu $(C I=250 \mathrm{kPa})$ do nagiba terena od $5 \%$, sa stajališta okolišne pogodnosti u cilju smanjenja oštećivanja tla vuča drva uz nagib terena teretima koji osiguravaju djelotvorno korištenje skidera Ecotrac $55 \mathrm{~V}$ $(1,5 \mathrm{t}-2 \mathrm{t})$ vezana je uz nosivost tla $>500 \mathrm{kPa}$ (slika 6B).

Na primjeru skidera Ecotrac 55V (slika 6B), predloženi model procjene raspona kretnosti skidera ovisno o nagibu terena te količini (masi) vučenog drva, pri vuči tereta od $1,5 \mathrm{t}$ potvrdio je opće prihvaćeni raspon kretnosti šumskih vozila od 33\% nagiba (MacDonald 1999) te pri vuči od $2 \mathrm{t}$ potvrdio je i smjernice o dopuštenim uzdužnim nagibima traktorskih putova $(<20 \%)$. Pri većim nagibima sekundarnih šumskih prometnica, raste pojavnost sabijanja tla (Jourgholami i dr. 2020A, Solgi i dr. 2019B) te neželjene pluvijalne erozije tla (Jourgholami i dr. 2020B, Solgi i dr. 2019A).

Posebno valja istaknuti da prikazana simulacija modela kretnosti skidera pri privlačenju drva uz nagib terena opisuje dio kretnosti skidera, koju valja nadopuniti s simulacijom kretnosti skidera niz nagib terena (Đuka 2014, Đuka i dr. 2016, Đuka i dr. 2018A), ali i sa ostalim pokazateljima 
prohodnosti vozila, poput prednjeg, središnjeg i stražnjeg kuta prohodnosti te poprečnog i uzdužnog polumjera prohodnosti (Poršinsky i dr. 2016) sa ciljem izrade alata za ocjenjivanja pogodnosti šumskih vozila prilikom postupaka njihove nabavke, odnosno planiranja izvođenja radova pridobivanja drva.

\section{UMJESTO ZAKLJUČKA INSTEAD OF THE CONCLUSION}

Na primjeru skidera s vitlom, prikazan je simulacijski model procjene kretnosti šumskih vozila pri privlačenju drva uz nagib terena. Predstavljeni model omogućuje poimanje promjena vertikalnih, horizontalnih, frikcijskih i trakcijskih sila pri privlačenju drva skiderom uslijed širokih raspona promjena utjecajnih čimbenika: 1) količine vučenoga drva, 2) nagiba terena te 3) uvjeta nosivosti podloge iskazane konusnim indeksom tla. Ugradnjom kriterija/ograničenja privlačenja drva proisteklih iz prethodnih istraživanja, model kretnosti skidera dobiva na uporabnome značenju, odnosno teorijski pristup približava stvarnosti privlačenja drva. Važnost prikazanoga modela procjene kretnosti svakako se ogleda u činjenici da je moguće, sa zadovoljavajućom točnošću, doći do bitnih spoznaja vezanih uz kretnost šumskih vozila bez dugotrajnih i skupih terenskih istraživanja, čija je primjenjivost vezana za istraživano šumsko vozilo i uvjete u kojima su mjerenja vršena.

Prikazani model kretnosti je zasnovan na lako mjerljivim ili dostupnim podacima šumskih vozila (masa, gabaritne dimenzije), ali i jednom teže mjerljivom, odnosno nedostupnom podatku iz kataloga proizvođača šumskih vozila - položaju točke težišta, koji u postupku nabava od proizvođača treba dodatno zatražiti. Isto tako, izrada modela kretnosti skidera zahtijeva poznavanje vrijednosti faktora privlačenja i raspodjele mase tereta u ovisnosti o utjecajnim čimbenicima privlačenja drva, kao što su: udužni nagib vlake (terena) i smjer nagiba, masa (ili obujam) tereta, duljina vučenoga tereta. U slučaju njihovoga nepoznavanja preporuča se korištenje njihovih vrijednosti u iznosu od 0,5 , što je u skladu s prosječnim vrijednostima utvrđenih mjerenjima iz više prethodnih objava.

Dopunjavanjem prikazanog modela, kriterijima/ograničenjima privlačenja drva niz nagib terena (Đuka 2014, Đuka i dr. 2016, Đuka i dr. 2018A): 1) Graničnog nagiba terena kod kojeg vučna sila poprima vrijednost nula (početak kočenja motorom vozila) te 2) Graničnog nagiba terena pri kojem vučeno drvo počinje gurati skider (određeno trenutkom kada horizontalna sastavnica sile u užetu poprimi vrijednost nula), model procjene kretnosti skidera dobio bi šire značenje uslijed primjenjivosti na oba smjera privlačenja drva.

U cilju privlačenja drva na djelotvoran, siguran i okolišno prihvatljiv način, prikazani model procjene kretnosti ski- dera svoju primjenu će naći kod: 1) šumarskih stručnjaka kao alat ocjenjivanja pogodnosti šumskih vozila prilikom njihove nabavke, odnosno planiranja mehaniziranog privlačenja drva sa ciljem povećanja djelotvornosti sustava, ali i smanjivanja troškova popravaka i održavanja strojeva, te 2) studenata šumarskih fakulteta tijekom njihovoga školovanja.

\section{ZAHVALA}

\section{ACKNOWLEDGEMENT}

Istraživanje je provedeno u sklopu projekta »Očuvanje sastojina poljskog jasena (Fraxinus angustifolia Vahl) u Republici Hrvatskoj sa naglaskom na biotske štetnike« koji financira Ministarstva poljoprivrede Republike Hrvatske.

\section{LITERATURA}

REFERENCES

- Bennett, W.D., 1962: Forces Involved in Skidding Full Trees and Tree-length Loads of Pulpwood. Pulp and Manager Magazine of Canada, Woodland Section Index No. 2162: 322-327.

- Brixius, W.W., 1987: Traction prediction equations for bias ply tires. ASAE Paper No. 87-1622: 31p.

- Bygden, G., 2012: GIS for Operative Support. In: Global Perspectives on Sustainable Forest Management (ed: C. A. Okia), In Tech, 217-222.

- Đuka, A., 2014: Razvoj modela prometnosti terena za planiranje privlačenja drva skiderom. Disertacija, Šumarski fakultet Sveučilišta u Zagrebu, 1-303.

- Đuka, A., S., Grigolato, I., Papa, T., Pentek, T., Poršinsky, 2017: Assessment of timber extraction distance and skid road network in steep karst terrain. iForest - Biogeosciences and Forestry 10: 886-894

- Đuka, A., T., Pentek, D., Horvat, T., Poršinsky, 2016: Modelling of Downhill Timber Skidding: Bigger Load - Bigger Slope. Croat. j. for. eng. 37(1): 139-150.

- Đuka, A., T., Poršinsky, T., Pentek, Z., Pandur, D., Vusić, I., Papa, 2018A: Mobility Range of a Cable Skidder for Timber Extraction on Sloped Terrain. Forests 9(9): 526.

- Đuka, A., T., Poršinsky, T., Pentek, Z., Pandur, D., Janeš, I., Papa, 2018B: Soil Measurements in the Context of Planning Harvesting Operations and Variable Climatic Conditions. SEEFOR 9(1): 61-71.

- Eichrodt, A.W., H.R., Heinimann, 2001: Mobility of Timber Harvesting Vehicles. Proceedings »Appalachian Hardwoods: Managing Change«, Council on Forest Engineering (COFE), July 15-18, 2001, Snowshoe, USA, 1-6.

- Eichrodt, A.W., 2003: Development of a Spatial Trafficability Evaluation System. PhD Thesis, ETH Zurich, 1-165.

- Hassan, A.E., 1977: Trafficability Study of a Cable Skidder. Transactions of the ASAE 20(1): 26-29.

- Hassan, A.E., A.L., Gustafson, 1983: Factors Affecting Tree Skidding Forces. Transactions of the ASAE 81-1586: 47-53.

- Hassan, A.E., D.L., Sirois, 1983: Weight Distribution Characteristics of Semi-Suspended Trees. Transactions of the ASAE 83-2605: 1291-1297. 
- Holzfeind, T., C., Kanzian, K., Stampfer, F., Holzleitner, 2019: Assessing Cable Tensile Forces and Machine Tilt of Winch-Assisted Forwarders on Steep Terrain under Real Working Conditions. Croat. j. for. eng. 40(2): 281-296. https://doi. org/10.5552/crojfe.2019.621

- Horvat, D., 1990: Predviđanje vučnih karakteristika šumskog zglobnog traktora - skidera. Meh. šumar. 15(7-8): 113-118.

- ISO 13861, 2000: Machinery for forestry - Wheeled skidders - Terms, definitions and commercial specifications, 1-9.

- Jourgholami, M., S., Khajavi, E.R., Labelle, 2020A: Recovery of Forest Soil Chemical Properties Following Soil Rehabilitation Treatments: an Assessment Six Years after Machine Impact. Croat. j. for. eng. 41(1): 163-175. https://doi.org/10.5552/crojfe. 2020.620

- Jourgholami, M., M., Ahmadi, F., Tavankar, R., Picchio, 2020B: Effectiveness of Three Post-Harvest Rehabilitation Treatments for Runoff and Sediment Reduction on Skid Trails in the Hyrcanian Forests. Croat. j. for. eng. 41(2): 309-324. https://doi. org/10.5552/crojfe.2020.732

- Kajgana, V., 2014: Analiza kretnosti skidera Ecotrac 55V. Diplomski rad, Šumarski fakultet Sveučilišta u Zagrebu, 1-67.

- Labelle, E.R., K.J., Lemmer, 2019: Selected Environmental Impacts of Forest Harvesting Operations with Varying Degree of Mechanization. Croat. j. for. eng. 40(2): 239-257. https://doi. org/10.5552/crojfe.2019.537

- Lubello, D., 2008: A rule based SDSS for integrated forest harvesting planning. $\mathrm{PhD}$ Thesis, Universita degli studi di Padova, Padova, 1-213.

- MacDonald, AJ., 1999: Harvesting Systems and Equipment in British Columbia. FERIC, Handbook No., HB-12: 1-197.

- Marčeta, D., V., Petković, D., Ljubojević, I., Potočnik, 2020: Harvesting System Suitability as Decision Support in Selection Cutting Forest Management in Northwest Bosnia and Herzegovina. Croat. j. for. eng. 41(2): 251-265. https://doi.org/10.5552/crojfe.2020.744

- Mellgren, P.G., 1980: Terrain Classification for Canadan Forestry. Canadian Pulp and Paper Association, 1-13.

- Poršinsky, T., 2005: Djelotvornost i ekološka pogodnost forvardera Timberjack 1710 pri izvoženju oblovine iz nizinskih šuma Hrvatske. Disertacija, Šumarski fakultet Sveučilišta u Zagrebu, $1-170$.

- Poršinsky, T., D., Horvat, 2005: Indeks kotača kao parametar procjene okolišne prihvatljivosti vozila za privlačenje drva. Nova meh. šumar. 26: 25-38.

- Poršinsky, T., M., Sraka, I., Stankić, 2006: Comparison of Two Approaches to Soil Strength Classifications. Croat. j. for. eng. 27(1): 17-26.

- Poršinsky, T., I., Stankić, A., Bosner, 2011: Ecoefficient Timber Forwarding Based on Nominal Ground Pressure Analysis. Croat. j. for. eng. 31(1): 345-356.

- Poršinsky, T., M., Šušnjar, A., Đuka, 2012: Određivanje faktora raspodjele mase tereta i privlačenja. Nova meh. šumar. 33: $35-44$.
- Poršinsky, T., M., Moro, A., Đuka, 2016: Maneuverability Characteristics of Cable Skidder. Šum. list 140(5-6): 259-272.

- Poršinsky, T., J., Matas, D., Horvat, A., Đuka, 2020: Pneumatici kotača šumskih vozila (Tyres of Forestry Vehicles). Šum. list 144 (9-10): 509-522. https://doi.org/10.31298/sl.144.9-10.7

- Saarilahti, M., 2002: Soil interaction model. Project deliverable D2 (Work package No. 1) of the Development of a Protocol for Ecoefficient Wood Harvesting on Sensitive Sites (ECOWOOD). EU 5th Framework Project (Quality of Life and Management of Living Resources) Contract No. QLK5-1999-00991 (19992002), 1-87.

- Sever, S., 1980: Istraživanje nekih eksploatacijskih parametara traktora kod privlačenja drva. Disertacija, Šumarski fakultet Sveučilišta u Zagrebu, Zagreb, 1-301.

- Solgi, A., R., Naghdi, E.R., Labelle, F.K., Behjou, V., Hemmati, 2019A: Evaluation of Different Best Management Practices for Erosion Control on Machine Operating Trails. Croat. j. for. eng. 40(2): 319-326. https://doi.org/10.5552/crojfe.2019.532

- Solgi, A., R., Naghdi, E.K., Zenner, P.A., Tsioras, V., Hemmati, 2019B: Effects of Ground-Based Skidding on Soil Physical Properties in Skid Trail Switchbacks. Croat. j. for. eng. 40(2): 341350. https://doi.org/10.5552/crojfe.2019.535

- Šušnjar, M., 2005: Istraživanje međusobne ovisnosti značajki tla traktorske vlake i vučne značajke skidera. Disertacija, Šumarski fakultet Sveučilišta u Zagrebu, 1-146.

- Šušnjar, M., D., Horvat, 2006: Dinamičko opterećenje kotača skidera pri privlačenju drva. Glas. šum. pokuse, posebno izd., 5: 601-616.

- Šušnjar, M., A., Bosner, T., Poršinsky, 2010: Vučne značajke skidera pri privlačenju drva niz nagib. Nova meh. šumar. 31 : 3-14.

- Tomašić, Ž., 2007: Istraživanje tehničko-eksploatacijskih značajki skidera za prorede. Disertacija, Šumarski fakultet Sveučilišta u Zagrebu, 1-316.

- Tomašić, Ž., D., Horvat, M., Šušnjar, 2007: Raspodjela opterećenja kotača skidera pri privlačenju drva. Nova meh. šumar. 28: 27-36.

- Tomašić, Ž., M., Šušnjar, D., Horvat, Z., Pandur, 2009: Forces Affecting Timber Skidding. Croat. j. for. eng. 30(2): 127-139.

- Tomašić, Ž., 2012: Razvoj tehnologije i tehničkih sredstava u pridobivanju drva s obzirom na posebnosti šuma i šumarstva u Republici Hrvatskoj. Nova meh. šumar. 33: 53-67.

- Weise, G., L., Nick, 2003: Determining the performance and the environmental impact of forest machines - Classification numbers and performance diagrams. Proceedings of Austro2003 High Tech Forest Operations for Mountainous Terrain, October 5-9, 2003, Schlaegl, Austria, University of Natural Resources and Applied Life Sciences Viena, CD-ROM, 1-10.

- Wronski, E.B., N., Humphreys, 1994: A method for evaluating the cumulative impact of ground-based logging systems on soils. Journal of Forest Engineering 5(2): 9-20.

- Zorić, M., Z., Pandur, Ž., Šantek, M., Šušnjar, 2011: Ocjena indeksa kotača kao pokazatelja okolišne pogodnosti forvardera. Nova meh. šumar. 32: 5-13. 


\section{SUMIMARY}

Based on the dimensional characteristics of the cable skidder (dimensions, weight, position of the center of gravity), a model was developed for estimating the mobility of the skidder during timber extraction (skidding) uphill in a safe, efficient and environmentally sound way. The model is based on the limiting slope of skidders' mobility depending on the traction performance of the vehicle, which connects two research approaches, 1 ) vehicle - terrain (distribution of forces depending on the slope and load) and 2) wheel - soil (traction performance based on wheel numeric). The model is in compliance with a number of restrictions arising from previous research: i) unloading the front axle of the vehicle, ii) overloading the rear axle of the vehicle, iii) minimum longitudinal stability of the skidder, iv) minimal soil bearing capacity and v) allowed tyre load capacity.

The results of the mobility of the cable skidder Ecotrac 55V equipped with 12.4-24 tires during skidding timber uphill, differ significantly with regard to the load-bearing capacity and the load size. For smaller loads, weighing up to 1 ton, the mobility of the skidder is determined by the criteria/limits of the skidder gradeability (traction performance) and environmental benefits (minimum load-bearing capacity). As the weight of the load increases, apart from the load-bearing capacity, the decisive limiting factor of mobility becomes the load ratio of the front and rear axles of the vehicle ( $>1: 3.5)$, which limits the mobility of the skidder on slopes $<33 \%$ for loads of 1.5 tons, $<20 \%$ for 2 tons. At a load of 2.5 tons, the mobility of the skidder is affected by the criteria of the maximum allowable load of the rear axle of the skidder on slopes $<7 \%$.

KEY WORDS: cable skidder, uphill skidding, gradeability, traction performance 